\title{
THE SUPPRESSION OF PIRATE RADIO BROADCASTING: A TEST CASE OF THE INTERNATIONAL SYSTEM FOR CONTROL OF ACTIVITIES OUTSIDE NATIONAL TERRITORY
}

\author{
HORACE B. ROBERTSON, JR.*
}

I

INTRODUCTION

In the mid-1960's as many as eleven unauthorized broadcasting stations were operating from ships or fixed platforms in the coastal waters off Northern Europe and Great Britain." These sea-based broadcasting stations, dubbed "pirate" broadcasters by the popular press, first appeared in $1958,{ }^{2}$ flourished for a few years, but then vanished from the airways. The last station, Radio Caroline, managed to remain on the air from time to time until it sank in a storm in $1979 .{ }^{3}$ That even one such station was in existence until only a few years ago, despite significant individual and concerted efforts by the European states to close them down, indicates that pirate radio stations filled a need not met by local broadcasting facilities, ${ }^{4}$ and served a constituency of sufficient strength to make effective action against them difficult. ${ }^{5}$ As the "pirate radio ship of the 1980's" - a space satellite capable of direct radio and TV broadcasts to ground receivers- becomes a reality, it is appropriate to examine the rise of the pirate stations, the reasons they flourished, the problems encountered in suppressing them, and the jurisdictional theories of international law relied upon in eventually bringing them under control.

The Origin of Pirate Radio Broadcasting

Pirate radio stations flourished in the late 1950's and early to mid-1960's because they filled a need that was not being met by existing broadcasting facili-

Copyright (C) 1982 by Law and Contemporary Problems

* Professor of Law, Duke University School of Law. The author wishes to express his appreciation to Richard W. Evans, Duke University School of Law, Class of 1982, for his assistance in the preparation of this article.

1. B. Paulu, Radio and Television Broadcasting on the Elroplan Continent 22 (1967).

2. Hunnings, Pirate Broadcasting in European Waters, 14 INT'L \& CoMP. L.Q. 410,418 (1965).

3. 178 E.B.U. REV. TECH. 306 (1979).

4. D. Smith, International Telecommunication Control $96-98$ (1969).

5. Id.; Woodliffe, Some Legal Aspects of Pirale Broadcasting in the North Sea, 12 NetherLands INT'L L. REV. 365, 366-67 (1965). 
ties. Then, as now, broadcasting in most European countries was a state monopoly. ${ }^{6}$ It was, as well, almost exclusively noncommercial, usually supported by the license or subscription fees of listeners and viewers. ${ }^{7}$ Programming was generally quite limited, traditional, and slow to adjust to the changing musical tastes of the listening audience, particularly to the young's craze for "pop" or rock music of the era. ${ }^{8}$ In Britain, the target of the largest number of pirate stations, BBC's so-called Light Programme made little effort to cater to the rise in popularity of the American-style, disc-jockey-oriented, continuous popular programming. ${ }^{9}$

That a market existed for rock programming was demonstrated by the success of several broadcasting stations operating from the few states that did permit commercial broadcasting. ${ }^{10}$ Radio Luxembourg, Radio Andorra, and Radio-TV Monte Carlo, each with powerful transmitters aimed not only at local audiences but also at the populations of nearby countries, were notable examples. ${ }^{1}$ There was; then, clearly a market for additional commercial stations providing continuous music programming. But the territories and frequencies available for such land-based broadcasting were strictly limited by national regulations. ${ }^{12}$ As a result, entrepreneurs desiring to tap this market were forced to establish their facilities outside the jurisdiction of any state. The high seas provided the obvious location. Thus, the birth of the pirate radio station-a station located either on a floating platform (ship or barge) anchored or steaming outside the territorial waters of any state ${ }^{13}$ or on a fixed platform built in shallow waters outside the territorial sea. ${ }^{14}$

To understand why broadcasting entrepreneurs were forced out to sea, the national and international regulatory framework for radio broadcasting must be examined.

\section{III}

\section{The National and InTERnational Systems for Regulating RADIO BROADCASTING}

Soon after the invention of radio, most states recognized the need for regulation of radio transmissions to prevent interference between users, and enacted national legislation to allocate frequencies and regulate transmissions of radio sig-

6. See Hunnings, supra note 3, at 415-46. See generally B. PAULU, supra note 1, at 58-89.

7. B. Paulu, supra note 1 , at 90-94.

8. See D. SMITH, supra note 4, at 96-98.

9. P. Harris, When Pirates Ruled the Waves 32 (4th ed. 1970).

10. Id. at $52-53$.

11. See Hunnings, supra note 2, at 4.16 .

12. See supra note 6 and accompanying text.

13. A variety of craft, including a ferry boat, a Liberty ship, a mine sweeper, lightships, and coasters, were converted into seagoing broadcasting stations. See P. HARRIS, supra note 9, at 207-16.

14. Several abandoned World War II antiaircraft forts (Martello towers) located off the coast of Great Britain were used as broadcasting platforms. Hunnings, supra note 2, at 412 ; P. HARRIS, supra note 9 , at 207-16. An artificial structure was built off the coast of the Netherlands for use specifically as a broadcasting platform. Van Panhuys \& van Emde Boas, Legal Aspects of Pirate Broadcasting: A Dulch Approach, 60 AM. J. INT'L L. 303, 303-04 (1966). 
nals. Since, however, radio signals, unlike wire transmissions, had no fixed terminal points and crossed international borders indiscriminately, it became apparent quite early that international as well as national regulatory measures were needed. ${ }^{15}$

The current international regulatory body, the International Telecommunication Union, a specialized agency of the United Nations with headquarters in Geneva, originated in 1865 as the International Telegraph Union, which was itself established, as its name suggests, to regulate telegraph communications. ${ }^{16}$ With the advent of radio, the International Telegraph Union assumed jurisdiction of that field, holding its first International Radio Conference in 1906. ${ }^{17}$ Since that time, it has held periodic international conferences and adopted a number of international conventions allocating the radio spectrum among different uses and by geographical regions. ${ }^{18}$ At the 1932 conference in Madrid, the name of the organization was changed to the International Telecommunication Union (ITU) to reflect its broader sphere of interest. ${ }^{13}$ The currently effective International Telecommunication Convention (which is the international convention from which the ITU derives its authority) was negotiated in Malaga-Torremolinos in 1973 and entered into force in 1976.20 The actual allocation of frequencies and detailed regulation of radio emissions are undertaken in periodic general and specialized administrative conferences, and the resulting regulations are annexed to the effective telecommunication convention. ${ }^{21}$

The conventions establishing the ITU and the regulations implementing and governing its operations do not, however, give it any enforcement power. These powers reside in individual state parties. ${ }^{22}$ Further, allocations of specific frequencies are not made directly to states by the ITU or its operating bodies, but rather are left to regional cooperation. ${ }^{23}$ In Europe, for example, country-by-country assignments were undertaken in a series of plans (such as the Geneva and Lucerne

15. D. SMITH, supra note 4 , at 18.

16. M. Feldman, The Role of the United States in the International Telecommunication Union and Pre-ITU Conferences 4 (1975);B. Paulu, supra note 1, at 9.

17. B. Paulu, supra note 1 , at 11 .

18. Id. at 12 .

19. Id. at 11 .

20. International Telecommunication Convention, Oct. 25, 1973, 28 U.S.T. 2495, T.I.A.S. No. 8572 (entered into force with respect to the United States Apr. 7, 1976).

21. Radio Regulations, Dec. 21, 1959, 12 U.S.T. 2377, T.I.A.S. No. 4893; Partial Revision of Radio Regulations, Nov. 8, 1963, Additional Protocol, 15 U.S.T. 887, T.I.A.S. No. 5603 (radio bands for space radiocommunications purposes); Partial Revision of Radio Regulations, Apr. 29, 1966, Additional Protocol, 18 U.S.T. 2091, T.I.A.S. No. 6332 (aeronautical mobile service); Partial Revision of Radio Regulations, Nov. 3, 1967, Final Protocol: Maritime Mobile Service, 19 U.S.T. 6717, T.I.A.S. No. 6590 (maritime mobile service); Partial Revision of Radio Regulations, July 17, 1971, Final Protocol: Space Telecommunications, 23 U.S.T. 1527, T.I.A.S. No. 7435 (space telecommunications); Partial Revision of Radio Regulations, June 8, 1974, Final Protocol: Maritime Radio, 28 U.S.T. 3909, T.I.A.S. 8599 (radio-telephone coast stations); Partial Revision of Radio Regulations, Mar. 5, 1978, Final Protocol: Aeronautical Mobile (R) Service, T.I.A.S. 9920 (aeronautical mobile service). For a comprehensive discussion of the ITU regulatory scheme and the most recent World Administrative Radio Conference (1979), see Robinson, Regulating Intemational Ainwaves: The 1979 WARC, 21 VA. J. INT'L. L. 1, 6-12 (1980).

22. See, e.g., International Telecommunication Convention, supra note 20, preamble, arts. 24, 35 $\S \S 2-3,37,44,50$.

23. Id. art. $7 \S 3(2)$; Radio Regulations, Dec. 21 , 1959, supra note 21, art. 5. 
plans), the latest of which are the Copenhagen Plan of 1948 for AM radio broadcast frequencies and the Stockholm Plans of 1952 and 1961 for television and FM. ${ }^{24}$ At the time pirate radio stations began appearing off the coast of Europe, several European states were not yet parties to the Copenhagen Convention of 1948. ${ }^{25}$ Even some of those that were parties failed to live up to their enforcement obligations. ${ }^{26}$ Thus, the existing international plan for the allocation of broadcasting frequencies in Europe was not fully effective. For example, the European Broadcasting Union reported that on May 1, 1967, 9 of 26 longwave and 315 of 521 mediumwave stations were operating outside the Copenhagen Plan. ${ }^{27}$

Nevertheless, despite this widespread nonobservance of its regulations for the operation of broadcasting stations within national territories, the ITU adopted a rule in 1959 which was directed to the suppression of radio broadcasting occurring outside the national territory of any state. It provided: "The establishment and use of broadcasting stations (sound broadcasting and television broadcasting stations) on board ships, aircraft or any other floating or airborne objects outside national territories is prohibited." 28 Of course, since the ITU itself had no enforcement authority, enforcement was left to individual states. ${ }^{29}$ The convention did not suggest how states were to accomplish this, but the conference urged states to study the means to do so. ${ }^{30}$ A review of the possible means open to states to extend the jursidictional reach of their national enforcement authority, the theoretical bases for those means, and how the various means worked in practice makes up the bulk of the remainder of this paper. Before proceeding to those issues, however, the paper explores the reasons that states were concerned about stamping out pirate broadcasting.

24. B. Paulu, supra note 1 , at 13-14.

25. Id. at 14 n.t.

26. Id. at 14-15.

27. Id. at 15, n. $\dagger$.

28. Radio Regulations, Dec. 21, 1959, supra note 21, art. 7 1 (reg. 422). The Radio Regulations of the International Telecommunication Convention have contained restrictions directed at unauthorized broadcasts from the high seas since the 1938 Cairo Conference. D. SMITH, supra note 4, at 73-74; General Radio Regulations (Cairo Revision) Apr. 8, 1938, art. 21 (A) § 1(2), 54 Stat. 1417, 1523 (reg. 473), T.S. No. 948. The language of the original provision was modified in 1947, Radio Regulations annexed to the International Telecommunication Convention, Oct. 2, 1947, art. 28 § (reg. 579), 63 Stat. 1581, 1819, T.I.A.S. No. 1901, and again in 1959. It is now found in art. $28 \S 6$ (reg. 962) of the Radio Regulations: "The operation of a broadcasting service . . . by mobile stations at sea and over the sea is prohibited." Dec. 21, 1959, supra note 21. Broadcasting service is defined in the regulations as "[a] radiocommunication service in which transmissions are intended for direct reception by the general public. . . . [and which] may include sound transmissions, television transmissions or other types of transmissions." Id. art. 1 (reg. 28).

Concern over the application of regulation 962 to nonmobile, permanently moored vessels or to "floating islands" encouraged the 1959 conference to adopt a specific regulation aimed directly at pirate radio broadcasts. D. SMITH, supra note 4 , at 74 . The wording of this regulation (see text accompanying this note) refers only to floating and airborne objects and thus excludes stations resting on the seabed. Hunnings, supra note 2 , at 415 .

29. See supra text accompanying notes 22-26.

30. Van Panhuys \& van Emde Boas, supra note 14, at 307. 
IV

\section{Problems Presented by Pirate Broadcasting}

The basic problem presented by pirate radio stations was that they struck at the very heart of the comprehensive and sophisticated national and international regulatory schemes adopted by the international community to ensure order and noninterference between uses and users of the radio spectrum. Since the spectrum of radio frequencies allocated to radio broadcasting is limited ${ }^{31}$ and a large number of broadcasting stations were competing for places on the spectrum, the intrusion of broadcasting stations free to pick their own frequencies and radiatedpower levels was bound to create interference with other stations. Further, use of frequencies allocated to other purposes for broadcasting interfered with those other authorized uses. Although pirate radio stations attempted to select frequencies that would not interfere with others (out of self-interest in a clear channel as well as consideration for other stations), both of those types of interference were alleged to have occurred in Europe. ${ }^{32}$ Powerful British pirate stations were reported to have caused interference with broadcasting in Sweden, Belgium, Poland, Yugoslavia, Italy and Czechoslovakia. ${ }^{33}$ There were also reports of interference with maritime and aircraft communications. ${ }^{34}$

The large number of land-based stations operating in Europe during this period on unauthorized frequencies and at excessive power ${ }^{35}$ suggests, however, that the real problem European states found with sea-based pirate stations was not frequency interference but rather the threat posed to state radio monopolies. ${ }^{36}$ In 1966, a survey commissioned by one of the pirates, Radio Caroline, indicated that both Radio Caroline and Radio London, the two most successful of the pirates, had an audience of over $8,000,000$ listeners. ${ }^{37}$ Although the $\mathrm{BBC}$ claimed that the audience of all the pirates combined was only about one-quarter of the audience of its Light Programme and less than one-half of the Home Service program audience, ${ }^{38}$ the audience share of the pirates was impressive when it is recalled that they were only a few new stations pitted against the total array of BBC stations, all of which had been in operation for decades. This certainly says something about the popularity of the programming of the $\mathrm{BBC}$ in that era. ${ }^{39}$

Another of the problems presented by the pirates concerned copyright and performing rights. It was claimed that the pirates were successful at least in part because they were, in effect, getting a free ride since they paid no royalty, copyright, or performing-rights fees. ${ }^{40}$ The $\mathrm{BBC}$, on the other hand, had to purchase 12.

31. In Europe, the AM radio spectrum is $150-285 \mathrm{Kcs}$ and $525-1605 \mathrm{Kcs}$. B. PAULU, supra note 1 , at

32. P. HARRIS, supra note 9 , at 149.

33. Id.

34. B. PAULU, supro note 1 , at 22.

35. Smith, Pirate Broadcasting, 41 S. CAL. L. REv. 769, 810 (1968) [hereinafter cited as Pirate Broadcasting].

36. See, e.g., P. HARris, supra note 9, at 52-53; B. PAulu, supra note 1, at 22.

37. P. HARRIS, supro note 9, at 52-53; B. PAULU, supra note 1 , at 21.

38. B. PAULU, supra note 1 , at 21 .

39. See P. HARRIS, supra note 9, at 32 (quoting the Sunday Express). The BBC has since altered some of its programming. Pirale Broadcasting, supra note 35 , at 814.

40. Pirate Broadcasting, supra note 35 , at 773. 
the right to play a record from the recording company and then negotiate a separate agreement with the performing-rights holders in order to broadcast recorded music, the principal fare of the pirates. Moreover, the performing-rights agreements contained restrictions that did not encumber the pirates. These were the socalled needle time provisions, designed to limit the number of hours per week that the authorized stations could use recorded music. ${ }^{41}$ Such agreements were thought to be to the advantage of both the record manufacturers and performing artists who believed that if recorded music were used without limit, less time would be devoted to live music and fewer records would be sold. ${ }^{42}$

The pirate stations disputed both of these latter contentions. All of the leading British pirates claimed to have paid a percentage of their revenue to the performing-rights societies, ${ }^{43}$ and they also claimed that all of the offshore stations were "continuously assailed by record companies, promoters and musicians with requests to broadcast their work. Free and unsolicited records arrive[d] by almost every post."44 The two Dutch pirate stations complied with all Netherlands copyright and performing-rights laws. ${ }^{45}$ In addition, the pirates claimed that by broadcasting records from little known artists or recording companies, they played a substantial part in breaking the record monopoly in Great Britain where, in the early 1960's ninety-eight percent of all records sold bore the label of only four manufacturers. ${ }^{46}$ According to one claim, with the help of the pirates small record companies were able to get twenty percent of the market in three years. ${ }^{4}$

Finally, the pirate stations presented what might be called a sociological problem. Continuous rock music was considered by the British power structure as somehow morally decadent despite its substantial popularity. ${ }^{48}$ It epitomized the social turmoil of the 1960's, an era marked by long hair, eccentric clothes and free life style.

Although the pirates probably could have been put out of business in a few weeks if the conventional stations had adopted their programming, this solution was never adopted. Instead, all nations affected by the outbreak of radio piracy chose to seek other means of suppression, even reaching the point of government jamming of the transmissions of a particularly persistent pirate in 1970.49

\section{$\mathrm{V}$}

\section{The Legal Status of Pirate Radio Stations}

In a legal sense the term pirate connotes one who is an international outlaw, one whose conduct is so violent, lawless, reprehensible or threatening to the lawful activities of others on the high seas that he is universally condemned. He cannot

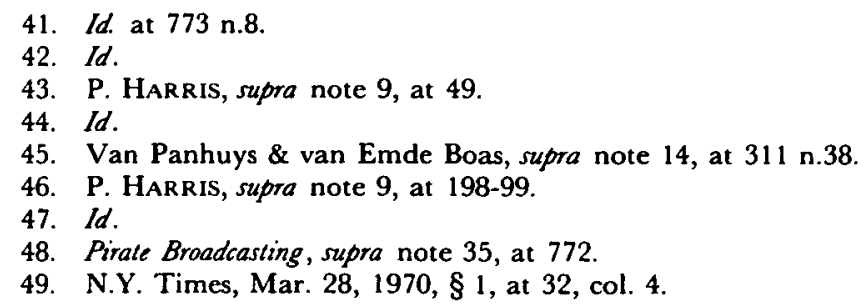


claim the protection of any state, and he is subject to universal jurisdiction. Any state can seize, try, and punish him whether he is found on the high seas or in any other place outside the jurisdiction of a state. This is the traditional status of pirates under both customary international law and the 1958 Convention on the High Seas. ${ }^{50}$ In the 19 th century, some states attempted to equate engaging in the slave trade to piracy, thereby authorizing universal jurisdiction over slave traders. This effort failed, and Great Britain, the leading proponent of this position, eventually conceded that it could act against slave trading nationals of other states only by virtue of a treaty. ${ }^{51}$ More recently, the nearly universal condemnation of aircraft hijacking and the widespread adherence to the antihijacking conventions have created nearly universal jurisdiction over aircraft hijackers. ${ }^{52}$

Despite their colorful appellation, no state has seriously suggested that radio pirates be equated to pirates in the legal sense. ${ }^{53}$ While their activity is unlawfulat least among states that are adherents to the Radio Regulations annexed to the 1973 Malaga-Torremolinos Convention ${ }^{54}$ and perhaps under a narrow interpretation of the 1958 Convention on the High Seas ${ }^{55}$-it is not of the violent and flagrant character which calls for the universal jurisdiction described above. ${ }^{56}$ States seeking to suppress radio pirates have turned to more conservative theories of jurisdiction on which to base their actions.

If radio pirates are not pirates in the legal sense, what is their status? Any analysis of the legal status of pirate stations operating on the high seas must proceed from two points: the nature and location of the platform (the station) from which the broadcast originates, and the nature of the activity involved (radio broadcasting).

All pirate radio stations that have existed to the present time have been located either on a ship anchored or steaming on the high seas or on an installation fixed to the seabed in shallow water outside the coastal state's territorial sea. ${ }^{57}$ The legal characteristics of each of these platforms will be examined below.

One of the prized freedoms of the seas which the traditional maritime states, including the Northern European states affected by pirate radio broadcasting, have assiduously sought to protect is the right of all states to sail ships on the high seas under their own flags. This right embraces a number of concepts. The essential ones, insofar as this analysis is concerned, are that a ship has the nationality of

50. Convention on the High Seas, Apr. 29, 1958, arts. 14-22, 13 U.S.T. 2312, T.I.A.S. No. 5200,450 U.N.T.S. 82 [hereinafter cited as High Seas Convention].

51. Hunnings, supra note 2, at 426. See also M. McDougal \& W. Burke, The Public Order or THE OCEANS 767, 881-85 (1962).

52. See, e.g., Convention for the Suppression of Unlawful Seizure of Aircraft (Hijacking), Dec. 16, 1970, 22 U.S.T. 1641, T.I.A.S. No. 7192; Convention on Offences and Certain Other Acts Committed on Board Aircraft, Sept. 14, 1963, 20 U.S.T. 2941, T.I.A.S. No. 6768, 704 U.N.T.S. 219.

53. But see infra notes $186-213$ and accompanying text (discussion of article 109 of the Draft Convention on the Law of the Sea).

54. See supra note 21 .

55. See infra text accompanying notes 71-75.

56. Pirate broadcasting activities are not piracy in the technical sense because they involve no "illegal acts of violence, detention or . . depradation . . . [o]n the high seas." High Seas Convention, supra note 50 , art. 15.

57. See supra note 14; Hunnings, supra note 2, at 410-12. 
its flag (registration), ${ }^{58}$ that each state has the right to determine the conditions for the grant of its nationality (flag), ${ }^{59}$ and that a ship on the high seas is immune from arrest or detention by the authorities of any state other than the state of its registration..$^{60}$ This last concept means that so long as a ship is on the high seas, even if engaged in an illegal activity other than piracy, only the flag state has enforcement jurisdiction over the ship. Thus, if the flag state is unwilling or unable to take enforcement measures against the ship, no other state can lawfully do so. If, however, a pirate radio ship should stray into the territorial sea of a coastal state, it is fully subject to the laws of the coastal state. There is no principle of international law which prevents a coastal state from exercising its enforcement jurisdiction against the foreign-flag ship for any violations of the coastal state's laws which may have been committed while the ship was within the territorial sea. ${ }^{61}$ The ship's immunity applies only on the high seas.

The status of platforms fixed to the seabed beyond the territorial sea is not quite so clear.62 Until the adoption of the Continental Shelf Convention in 1958, no customary international law of fixed platforms paralleling the customary law as to the legal status of ships had developed. ${ }^{63}$ That convention gives each coastal state the exclusive right "to construct and maintain or operate on the continental shelf installations and other devices necessary for its exploration and the exploitation of its natural resources."64 Further, the convention provides that such installations are "under the jurisdiction of the coastal state."65 Thus, insofar as the explicit provisions of the convention are involved, there is no authority either for or against the exercise of coastal state jurisdiction over installations affixed to the shelf unless those installations were constructed or are used for exploration or exploitation of the shelf resources. It certainly could be argued that the convention itself does not prohibit any state from constructing a platform on the continental shelf of another state so long as that platform is not intended or used for resource exploration or exploitation, and as long as it does not interfere with either the coastal state's own exploration or exploitation or its research undertaken there. The jurisdictional status of such a structure would, however, be cloudy. An argument could be made that because of the legal vacuum, the state authorizing construction should have jurisdiction, ${ }^{66}$ but an equally valid argument could be made on behalf of coastal-state jurisdiction based on contiguity. ${ }^{67}$

58. High Seas Convention, supra note 50 , art. 5 .

59. Id.

60. Id. arts. $6,11,22$.

61. Convention on the Territorial Sea and the Contiguous Zone, Apr. 29, 1958, art. 1, 15 U.S.T. 1606,

T.I.A.S. No. 5639, 516 U.N.T.S. 205 [hereinafter cited as Territorial Sea Convention].

62: See generally N. Papadakis, The InTERnational Legal Regime of ARTIriCial Islands 89-103 (1977).

63. Id. at 90 .

64. Law of the Sea: Convention on the Continental Shelf, Apr. 29, 1958, art. $5 \S 2,15$ U.S.T. 471,

T.I.A.S. No. 5578, 499 U.N.T.S. 311 [hereinafter cited as Continental Shelf Convention].

65. Id. art. $5 \S 4$.

66. See N. Papadakis, supra note 62, at 129-30; Pirate Broadcasting, supra note 35, at 780-82; van Panhuys \& van Emde Boas, supra note 14, at 320-22, 332-33.

67. See N. PaPadakis, supra note 62, at 130-31; Pirale Broadcasting, supra note 35, at 779-80; van Panhuys \& van Emde Boas, supra note 14, at 321-22, 334-35. 
Fortunately, the pirate stations that were built on fixed installations did not pose questions quite that complicated because only one state was involved. Those off the English coast were built on abandoned World War II antiaircraft towers constructed by the British Government ${ }^{68}$ and the single station on a built-to-order tower was Radio and TV Noordzee, which was erected by a private Dutch company just beyond the outer limits of the Netherlands territorial sea. ${ }^{69}$ In neither case, therefore, would the coastal state seeking to extend its jurisdiction and enforcement power to the towers face the prospect of another state purporting to exercise diplomatic protection on behalf of the tower, its occupants and activities. Nevertheless, as nations which had accepted international law as part of domestic law, ${ }^{70}$ both Great Britain and the Netherlands faced the issue of whether the reach of their domestic jurisdiction extended to towers fixed to the seabed of the continental shelf beyond their territorial seas. As shall be seen below, neither chose to base their jurisdictional claims on the continental shelf doctrine.

With regard to the activity involved, radio broadcasting, it must be determined whether this activity can be characterized as a freedom of the high seas.

The 1958 Geneva Convention on the High Seas, which is "generally declaratory of established principles of international law," 71 states that the high seas are open to all states. It further provides a specific enumeration of four freedomsnavigation, fishing, laying of pipelines and cables and flight-which, along with others "recognized by the general principles of international law," may be exercised by all states "with reasonable regard to the interests of other States in their exercise of the freedom of the high seas."72 The list does not explicitly include or exclude the freedom to broadcast from the high seas, but this omission of explicit reference is not dispositive of the question. Although some have argued that the freedoms of the high seas are limited to the four listed and activities similar to them, ${ }^{73}$ a broader interpretation, one embracing any peaceful activity not expressly prohibited by international law, is more consistent with the language of the article. Such an interpretation is also more logical and has received the support of eminent legal authorities. ${ }^{74}$ Adopting this broad interpretation, broadcasting from the high seas would presumptively be a freedom of the seas unless it came into conflict with some other prohibition of international law, or interfered with another state in its exercise of a freedom of the high seas. ${ }^{75}$

68. Hunnings, supra note 2, at $\mathbf{4 1 2}$.

69. Van Panhuys \& van Emde Boas, supra note 14, at 303.

70. See West Rand Cent. Gold Mining Co. v. The King, [1905] 2 K.B. 391; The Nyugat (Swiss Corporation Societé Anonyme Maritime et Commercial v. Netherlands), 10 Neder LaNDSE TyjDSCHRIFT VOOR INTERNATIONAL RECHT 82 (1963)(Hoge Road der Nederlanden, 1959).

71. High Seas Convention, supra note 50, preamble.

72. Id. art. 2.

73. C.J. Colombos quoted in N. PAPADAKIs, supra note 62, at 59; Pirate Broadcasting, supra note 35, at 776-78; Tammes, Freedom of the High Seas: Legitimacy of a "television island," 86B E.B.U. REV. GENERAL AND LEGAL. 38 (1964).

74. McDougal \& Burke, supra note 51, at 762-63; M. Mouton, The Continental. Shelf 228 (1952); Sir Humphrey Waldcock, quoted in N. PAPADAKIS, supra note 62, at 58; Pirale Broadcasting, supra note 35 , at $776-78$.

75. Presumably, broadcasting from the high seas might disturb the internal social order of the affected state. See supra note 48 . It would not, however, interfere with that state's freedom of the seas. Without 
Before discussing whether broadcasting in fact conflicts with some other prohibition or interferes with another state's exercise of a freedom, one must examine whether the freedoms of the high seas adhere to individuals or only to states. The language of the High Seas Convention would suggest that the latter is correct. Article 2 states that the high seas are "open to all nations,"76 and that the freedom of the high seas "comprises, inter alia, both for coastal and noncoastal States" the listed freedoms. ${ }^{77}$ It further provides that "all States" shall exercise these rights "with reasonable regard to the interests of other States."78 Article 4 provides that States shall have the right to sail ships. ${ }^{79}$ Other articles are cast in similar terms. ${ }^{80}$

The implication of this for entities that are not states conducting activities on the high seas is that any right they have is derivative of a state right. This is manifested in the case of ships by the requirement that a ship, to be entitled to sail the high seas, must be registered in some state in accordance with the law of that state. ${ }^{81}$ As a first-order requirement for legality, then, a ship carrying out broadcasting activities from the high seas would have to be registered in some state. A stateless ship being used for radio broadcasting from the high seas would be entitled to no protection whatever, ${ }^{82}$ and as a practical matter, would have no "parent" state to which it could turn for diplomatic protection if the authorities of a coastal state took action against it. But no owner of a pirate broadcasting ship would have been so foolish as to operate without registering the ship in some state, and, with the limited exceptions contained in article 22 of the High Seas Convention, ${ }^{83}$ only the state of registration would have competence to stop, board or arrest it on the high seas. ${ }^{84}$

In the case of fixed platforms, the law is less clear. As has been seen, with the exception of structures built on the continental shelf for resource exploration or exploitation, neither the Continental Shelf Convention nor customary international law addresses the relationship between a structure built on the continental shelf and the state whose nationals are carrying out activities on the structure. ${ }^{85}$

such a showing, such broadcasting would not be a violation of the High Seas Convention. See Pirate Broadcasting, supra note 35 , at 779 .

76. High Seas Convention, supra note 50, art. 2 (emphasis added).

77. Id. (emphasis added).

78. Id. (emphasis added).

79. Id. art. 4 (emphasis added).

80. See, e.g. id. art. 26, granting to states the right to lay submarine cables and pipelines.

81. See 1 L. Oppenheim, International Law 595 (8th ed. H. Lauterpacht 1955); High Seas Convention, supra note 50 , arts. $5 \S 1,6 \S 2$.

82. L. Oppenheim, supra note 81, at 595. See also Pirate Broadcasting, supra note 35, at 789.

83. Article $22 \S 1$ provides that, except in the execution of powers derived from a treaty, a warship may not stop and board a foreign-flag merchant ship on the high seas unless there is reasonable ground for suspecting that the ship is engaged in piracy or the slave trade or is "in reality, of the same nationality as the warship," though "flying a foreign flag or refusing to show its flag." High Seas Convention, supra note 50 , art. $22 \S 1$.

84. High Seas Convention, supra note 50, art. $6 \S 1$. Traditionally, also, a nation's attribution of nationality to a ship entitled to fly its flag has been deemed conclusive. See, e.g., L. OPPENHEIM, supra note 81, at 595; M. MCDougal \& W. BuRKE, supra note 51, at 1012, 1057-61. The ambiguous "genuine link" requirement of article 5 presents a possibility of mischievous subversion of this principle of exclusive competence. See id. at 1013-57. However, the author is not aware of any incidents suggesting that states have departed from the traditional view since the convention entered into force.

85. See supra text accompanying notes 62-69. 
The absence of such a legal relationship, analogous to that which exists between a ship and the state of registry, means that there is no state from which the nonstate entity can derive rights. It is hard, therefore, to find a basis on which someone carrying out a non-resource-related activity on a fixed platform could meet this first-order requirement for legality of his action as the exercise of a freedom of the high seas. A legal vacuum would exist with no clear guidelines to determine what state or states would be entitled to fill it. An analogy to stateless ships would not be appropriate, since there is no doctrine for structures affixed to the seabed corresponding to the doctrine of nationality for ships. ${ }^{86}$

Assuming for the purpose of further analysis, however, that the person or entity broadcasting from the high seas does meet the first-order requirement of having a derivative right to exercise a freedom of the high seas, the questions previously postponed-whether broadcasting from the high seas conflicts with some prohibition of international law or interferes with another state in its exercise of a freedom of the high seas-can now be addressed.

As briefly mentioned earlier, in 1959 the ITU adopted an administrative regulation (regulation 422) specifically aimed at pirate stations. ${ }^{87}$ It provided: "The establishment and use of broadcasting stations (sound broadcasting and television broadcasting stations) on board ships, aircraft or any other floating or airborne objects outside national territories is prohibited." 88 This provision supplemented an earlier rule, first adopted in 1938, which in its current revision provides that " $[\mathrm{t}]$ he operation of a broadcasting service by mobile stations at sea and over the sea is prohibited." 89 The apparent objective of the earlier rule was to protect essential radio communications at sea (ship-ship, ship-shore, aircraft-shore, etc.). Also it was narrowly drawn, applying only to mobile stations. ${ }^{90}$ Its applicability to anchored ships, even if capable of movement, was questionable. ${ }^{91}$ Regulation 422 , adopted in 1959 at the instigation of the Scandinavian states, was, however, aimed directly at pirate radio stations and was intended to remove the loophole as to nonmobile stations. ${ }^{92}$ Unfortunately even this regulation contained its own loophole. Since it applied only to stations on ships, aircraft or any foating or airborne object, ${ }^{93}$ it had no applicability to stations on platforms fixed to the seabed-a rather short-sighted omission.

A second ITU radio regulation, though not aimed only at broadcasting stations,

86. See N. PAPADAKIS, supra note 62, at 124-27. Papadakis suggests, however, that jurisdiction based on nationality of the owners of an installation would be sufficient to support jurisdiction over the installation. Id. at 127-29. See also infra text accompanying notes $140-50$ for discussion of nationality as a basis for jurisdiction.

87. See supra text accompanying note 28 .

88. Id.

89. See supra note 28 . The text of the 1938 regulation 473 is: "Mobile stations at sea shall be prohibited from making radiotelephone broadcast transmissions intended to be received by the general public." The text of the 1947 revision (regulation 579) is: "Broadcasting by mobile stations at sea and over the sea is prohibited."

90. Pirate Broadcasting, supra note 35 , at $798-99$ n.83.

91. Id.

92. Hunnings, supra note 2, at 414.

93. Radio Regulations, Dec. 21, 1959, supra note 21 , art. 7 1 (reg. 422). 
appears to be applicable to them. Regulation $725^{94}$ provides: "No transmitting station may be established or operated by a private person or by any enterprise without a license issued by the government of the country to which the station in question is subject." 95 This regulation is of general applicability, applying to landbased as well as extraterritorial stations. There are, as well, additional provisions applicable to ship-borne stations, ${ }^{96}$ including one allowing the authorities of portsof-call to inspect ships to determine whether the ships have a license and if manifest irregularities exist. ${ }^{97}$ The enforcement actions of these port-state authorities, however, are limited to the reporting of any irregularities to the flag state. ${ }^{98}$

Thus, as between states parties to the ITU regulations, the operation of a shipbased broadcasting station by ships registered in the territory of one of the states parties is contrary to international law.

Since, however, not all states are parties to the convention and regulations, these regulations are not universally binding unless it can be found that they are somehow declarative of customary international law or have ripened into a general norm. ${ }^{99}$ The convention and regulations are technical in nature and are, for the most part, concerned with allocating the radio spectrum among competing claimants and uses, so an argument that the provisions have become customary norms would be tenuous indeed. No state seeking to act against pirate radio stations has bottomed its actions on such a theory.

The argument that broadcasting from the high seas is not a freedom of the seas because it interferes with the interests of other states in their exercise of a freedom of the high seas also seems tenuous. 100 Although there may have been some isolated instances of pirate radio station interference with marine or air communications, the chance of this having been a serious problem was remote. After all, for pirate radio broadcasting to have been commercially successful, it had to reach a mass audience. To reach such an audience the pirate had to use the spectrum allocated to broadcasting because that was the band that listeners' sets were manufactured to receive. The audience for a private station broadcasting on a frequency lawfully allocated to some other use would have been nil. Although a badly tuned, malfunctioning, or poorly manufactured broadcasting transmitter might emit spurious signals that could interfere with other uses, such emissions would not render broadcasting as an activity an unreasonable interference with the other lawful activity. The broadcaster would, of course, have to clean up his signal, but if that were done the interference with other high seas uses would presumably disappear.

Broadcasting from the high seas, then, can arguably be characterized as a freedom of the high seas because its exercise is not without reasonable regard for

94. Id. art. $18 \S 1(1)$ (reg. 725).

95. Id.

96. Id. art. $21 \S \S 1-3$ (regs. 838-44).

97. Id. art. $21 \S 1(3)$ (reg. 840).

98. Id. arts. $21 \S 2(1)$ (reg. 842), $16 \S 1$ 1-3 (regs. 719-21).

99. See Baxter, Treaties and Custom, 129 RecueIL Des Cours 25, 99-101 (1970).

100. See supra text accompanying notes 73-75. 
the interests of other states in their exercise of a freedom of the high seas. ${ }^{101}$ The interference that the European states were in fact concerned with had much more to do with the invasion of the domestic airwaves by broadcasting signals contrary to established national and international regulatory schemes than it did with the freedom of seas, ${ }^{102}$ whether that invasion was in the form of actual radio-frequency interference with the signals of authorized stations or was the intrusion of unauthorized and unregulated alternative radio programming into the state-controlled monopoly.

\section{VI \\ RECAPITULATION}

At this point, a brief recapitulation of the points already developed is in order before proceeding to consider the legal bases which coastal states have or could have used to control pirate radio broadcasting.

- Pirate radio broadcasting stations, operated from ships or fixed platforms beyond the territorial limits of any state, flourished in the 1960's in European waters because they met a programming demand not fulfilled by European domestic stations.

- Broadcasting from floating objects (vessels) outside national territories (on the high seas) is arguably a freedom of the high seas under the High Seas Convention but is contrary to the radio regulations of the ITU.

- Enforcement of the radio regulations is a function of the individual states which are parties to the International Telecommunication Convention. For stations operating from ships outside national territory, the appropriate enforcing state is the state of registration (flag state) of the ship, which may or may not be a party to the convention and may or may not be disposed to take enforcement measures.

- Nonflag states normally do not have prescriptive or enforcement jurisdiction over ships outside their national territory.

- The jurisdictional status of platforms fixed to the bottom of the sea outside a national jurisdiction and intended for uses other than exploration or exploitation of the natural resources of the continental shelf is unclear. International law does not prescribe which, if any, state has jurisdiction over them or activities conducted on them.

With these points as background, the various legal theories that states have adopted or could adopt to suppress or control pirate broadcasting stations may be examined. 


\section{VII}

\section{Legal Theories Avallable for the Control of Pirate BROADCASTING}

\section{A. Territorial Jurisdiction}

The most pervasive jurisdiction exercised by a state is that exercised within its territory. There, a state's jurisdiction is complete and exclusive, extending to all persons, places, and activities. ${ }^{103}$ There is no question that any state may punish infringements of its laws occurring within its territory regardless of the nationality of the person or entity committing the act. ${ }^{104}$ For this purpose, the territorial sea is just as much a part of a state as its land territory ${ }^{105}$ and, except for the right of innocent passage and the limited immunity which that right gives to foreign ships while in such passage, ${ }^{106}$ is just as fully subject to the sovereignty of the state. ${ }^{107}$

It is obvious, then, that pirate stations would not consciously attempt to operate from within the territorial sea of a coastal state. Ship-based pirate stations cruised or anchored just outside the territorial waters of the target state ${ }^{108}$ and the fixed platforms constructed by broadcasters or the abandoned antiaircraft towers they occupied were also all outside the territorial sea. ${ }^{109}$ But even where a pirate broadcasting station was physically located outside the territory of a state, utilization of territorial jurisdiction theories afforded the state several methods of proceeding against it. Most states have traditionally exercised prescriptive jurisdiction over events taking place partly within their territory and partly outside. ${ }^{10}$ Some states have been more conservative in this regard than others, but international law does not restrain a state in its exercise of prescriptive jurisdiction over preparatory or supporting acts within its territory, even if the final acts rendering the event complete occur outside the territory. ${ }^{11}$ Neither does interna-

103. The Schooner Exchange v. M'Faddon, 11 U.S. (7 Cranch) 116 (1812); RESTATEMENT (SECOND) of Foreign Relations LaW of the United States $\$ \S 17-20$ (1965).

104. RESTATEMENT, supra note $103, \S \S 17,20$.

105. Id. $\$ 11$.

106. Territorial Sea Convention, supra note 61, arts. 1, 14-23.

107. Id. art. 1.

108. P. HARRIS, supra note 9, at 207-13.

109. Hunnings, supra note 2, at 422-23; van Panhuys \& van Emde Boas, supra note 14, at 303. Great Britain's initial efforts to close down pirate stations on abandoned Martello towers in the Thames Estuary in 1964 were aborted because the towers were outside the three mile limit measured from the traditional baselines used by Great Britain. Hunnings, supra note 2, at 423. After the Territorial Sea Convention became effective as to Great Britain, however, the government adopted bay closing lines authorized by article 7 of the convention by Order in Council. The Territorial Waters Order in Council, 1964, STAT. INST. app. $6452 \mathrm{~A}$ (1965). This brought the towers within the territorial sea. They then came within the prohibition of the Marine, \&c., Broadcasting (Offences) Act, 1967, ch. 41, $\$ 2(1)$ (a) which makes it unlawful to broadcast from "a structure in [the territorial sea of] the United Kingdom, being a structure affixed to, or supported by, the bed of those waters and not being a ship." Id. $\$ 21$ (a), (b), $\$ 2(2)$. The British Government was then able to close down the pirate stations on the Martello towers. See P. HARRIS, supra note 9, at 121-26. The British Marine, \&c., Broadcasting (Offences) Act, 1967 is summarized in Pirale Broadcasting, supra note 35 , at $806-10$.

110. See, e.g. , Harvard Research in International Law, Jurisdiction With Respect to Crime, 29 AM. J. INT'L L. Supp. 435, 484-87, 495-503; RESTATEMENT, supra note 103, $\$ 17$. Prescriptive jurisdiction is used here in the same sense as it is used in RESTATEMENT, supra note $103, \S 6$ comment.

111. RESTATEMENT, supra note $103, \$ 17$. 
tional law restrain a state from adopting a rule of law attaching legal consequences to an act occurring outside a state but having effects inside the territory. ${ }^{112}$

Under either of these theories, a target state would have considerable legal leverage over pirate radio broadcasting beamed at it. Because such a broadcasting enterprise could continue to operate only if it attracted enough advertising in the target state to meet its operating expenses and only if it received the necessary supporting services (fuel, food, personnel transport and operator rotation) from shore, sanctions against such activities would be effective in forcing a pirate out of existence. ${ }^{113}$ While some of the services might come from third countries, ${ }^{114}$ it is almost unavoidable that advertising revenue would have to come from the target state, ${ }^{15}$ for only advertisers of products or services sold in that state could hope to reap any benefit from radio advertising. It was, in fact, the case that all of the successful pirate stations in the 1960's had corporate headquarters or advertising branches or agencies within the target states. ${ }^{116}$ It was also true that most of the pirates were supplied and serviced from the ports of the target states. ${ }^{117}$ Clearly, if those states had had the political will and public support to enact legislation directed at the supplying and servicing of these stations, they would have not been acting contrary to international law. Indeed, this was the means eventually adopted by Great Britain to close down the pirates operating from ships off its coasts, but that action did not occur until after the member states of the Council of Europe adopted a convention obligating themselves to take such action. ${ }^{118}$

In a similar fashion, the objective-territorial theory of jurisdiction would have provided a legal basis for action against the pirates under certain circumstances. Under this theory, a state has prescriptive jurisdiction over acts occurring outside its territory if the conduct causes a direct, foreseeable and substantial effect within the territory, and either (1) the conduct and its effect are generally recognized as criminal or tortious, or (2) the prohibitory rule is not inconsistent with generally accepted principles of justice. ${ }^{119}$

While a state might not have been able to prescribe a rule against pirate radio broadcasting under the first of these criteria (criminal or tortious conduct), the second seems clearly to have been met. Pirate radio broadcasts did create substantial effects within the target state. They took audiences away from authorized

112. The S.S. Lotus, [1927] P.C.I.J., Ser. A, No. 10; see Harvard Research, supra note 110, at 487-94; RESTATEMENT, supra note $103, \$ 18$.

113. See, e.g., P. HARRIS, supra note 9, at 9. Radio Caroline was tended from Harwich. Caroline's parent company had offices in Mayfair. Id. at 16 .

114. After passage of the British Marine, \&c., Broadcasting (Offences) Act, 1967, Caroline was tended from, and its offices moved to, Amsterdam. Id. at 190.

115. Companies whose advertisements were heard over pirate radio stations after the passage of the British Marine, \&c., Broadcasting (Offences) Act, 1967, denied that they had purchased airtime. Their overseas parent companies also denied paying for airtime. Both forms of payment were illegal under the act. Holden, Alticus, Sunday Times (London), July 31, 1977, at 32, col. 1.

116. See supra note 114 .

117. Id.

118. Hunnings, supra note 2, at 422, 433. The convention, European Agreement for the Prevention of Broadcasts Transmitted from Stations Outside National Territories, Jan. 22, 1965, 634 U.N.T.S. 239, is reprinted in Hunnings at 434-36. The British action was also deferred until the enactment of the British Marine, \&c., Broadcasting (Offences) Act, 1967, supra note 109.

119. RestatemeNT, supra note $103, \S 18$. See also Harvard Research, supra note 110, at 487-94. 
stations, they often caused electronic interference with authorized uses, they injected a type of programming that was objectionable to the prevailing social order, and they sometimes introduced commercial broadcasting where only noncommercial had been approved. ${ }^{120}$ These intrusions were contrary to fundamental broadcasting policies adopted in most European states. And finally, as they were contrary to widely accepted international conventions, their prohibition could hardly be said to have been inconsistent with generally accepted principles of justice. ${ }^{121}$

The difficulty with use of the objective-territorial theory, however, lies not in the prescriptive right of the state but rather in enforcement. While prescriptive jurisdiction is the sine qua non of enforcement jurisdiction, ${ }^{122}$ prescriptive jurisdiction alone is not sufficient to permit enforcement. ${ }^{123}$ Some further connection with the territorial state is required. ${ }^{124}$ As the Permanent Court of International Justice stated in The Lotus, ${ }^{125}$ a state may exercise its prescriptive jurisdiction outside its territory unless there is some rule of international law which prohibits it from doing so, but that jurisdiction "cannot be exercised [enforced] by a State outside its territory except by virtue of a permissive rule derived from international custom or from a convention." 126

The usual permissive rule or basis for enforcement is territorial. That is, a state has jurisdiction to enforce within its territory a law validly prescribed by it and governing conduct outside its territory. ${ }^{127}$ Such a permissive rule might also be derived for fixed-platform stations from the continental shelf doctrine, but as has been seen, the national status of platforms not used for exploitation of the

120. See supra text accompanying notes $31-49$.

121. An argument might be constructed that such a prohibition would conflict with emerging principles concerning the freedom of communication across international boundaries. Article 19 of the Universal Declaration of Human Rights, G.A. Res. 217, U.N. Doc. A/810 (1948), states that "everyone has the right to freedom of opinion and expression; this right includes [the] freedom . . . to seek, receive and impart information and ideas through any media and regardless of frontiers" (emphasis added). Article 19(2) of the International Covenant on Civil and Political Rights, G.A. Res. 2200, 21 U.N. GAOR, Supp. (No. 16) at 52, U.N. Doc. A/6316 (1966) states, "Everyone shall have the right to freedom of expression; this right shall include freedom to seek, receive and impart information and ideas of all kinds, regardless of frontiers, . . . through any . . . media of his choice" (emphasis added). Article 10 of the Convention for the Protection of Human Rights and Fundamental Freedoms, Nov. 4, 1950, 213 U.N.T.S. 221 (1950), contains a provision almost identical to the words of article 19 of the Universal Declaration, but it is qualified by the statement "This Article shall not prevent States from requiring the licensing of broadcasting, television or cinema enterprises." Id. This is in accordance with radio regulation 725: "No transmitting station may be established or operated by a private person or any enterprise without a license issued by the government of the country to which the station is subject." Radio Regulation, Dec. 21, 1959, supra note 28, art. $18 \S 1$ (reg. 725).

For broadcasting stations within national territory then, the nations of the world appear to agree that the principle of freedom of communication must yield to the interest of avoidance of mutual interference. This apparently applies to broadcasting stations on the high seas as well, although, as has been indicated, a tenuous argument could be made that for nonparties to the ITU Regulations, broadcasting might be a freedom of the high seas. See supra text accompanying notes 99-102. But see Tammes, supra note 73, at 39.

122. The S.S. Lotus, [1927] P.C.I.J., Ser. A, No. 10; RestatemeNT, supra note 103, § 7(2) comment b.

123. RESTATEMENT, supra note 103, § 7(1).

124. See, e.g. , RESTATEMENT, supra note 103, $\$ \$ 20$ (within territory), 25 (by agreement), 32 (on board ships or aircraft of nationality of prescribing state).

125. The S.S. Lotus, [1927] P.C.I.J., Ser. A, No. 10.

126. Id. at 18-19.

127. RESTATEMENT, supra note $103, \S 20$. 
resources of the seabed is ambiguous. ${ }^{128}$ For ship-mounted stations, the nationality of the ship might provide the permissive basis, but it would be quite easy for a pirate station ship to avoid the coastal states' enforcement jurisdiction by adopting a flag-of-convenience nationality. ${ }^{129}$ The presence of agents, employees or components of the enterprise within the territory would thus seem to provide the best basis for exercising enforcement jurisdiction, for, as already mentioned, most pirate stations had substantial contact with the target state. Most maintained offices within the target state engaged in advertisement solicitation and other administrative activities; their broadcasting employees were local nationals who were ferried to and from the station from nearby national ports, and most support activities were carried out from nearby support bases in the target state. ${ }^{130}$ Each of these activities was a constituent element of the total operation. If a target state had enacted legislation making it unlawful to operate a broadcasting station on the high seas having a substantial effect within the territory of the state, or to aid or abet its operation, there is no apparent reason why such legislation could not have been enforced against those personnel and components of the operation that were physically within the territory of the state.

\section{B. Protective Jurisdiction}

Closely related to the objective-territorial theory of jurisdiction but distinct from it is the protective theory. Under this theory, a state has prescriptive jurisdiction over conduct outside its territory that threatens its security or the operation of its governmental functions if that conduct is generally recognized as criminal. ${ }^{131}$ It is not necessary that the effect of the conduct take place within the territory of the state, although in the usual case it would. Neither is it necessary that the person or entity against which the prescription is directed have the nationality of the prescribing state. ${ }^{132}$

The limits of conduct outside a state which falls within the range of this principle are not clear. In U.S. practice, the principle has been used to proscribe perjury before an official abroad or the making of false statements in a visa application. ${ }^{133}$ The United States has never used the principle to make unlawful the counterfeiting of money outside U.S. territory, however, although this is an obviously appropriate use. ${ }^{134}$ With regard to radio broadcasting, since the regulation and control of the airways (and in the case of some European states the actual operation of broadcasting facilities) are considered to be strictly governmental functions, and since pirate broadcasting obviously threatens the operation of these functions, the protective principle of jurisdiction would provide a basis for prescriptive jurisdiction. As in the case of jurisdiction grounded on the objective-

128. See supra text accompanying notes 62-69.

129. See Pirate Broadcasting, supra note 35 , at 812 .

130. See supra text accompanying notes 113-17.

131. Restatement, supta note $103, \S 33$.

132. United States v. Pizzarusso, 388 F.2d 8 (2d Cir.), cert. denied, 392 U.S. 936 (1968).

133. 22 U.S.C. $\$ 1203$ (1976); see United States v. Pizzarusso, 388 F.2d 8 (2d Cir.), cert. denied, 392 U.S. 936 (1968).

134. RESTATEMENT, supra note $103, \S 33$ reporter's note. 
territorial principle, enforcement would have to take place within the territory of the prescribing state or be based on one of the other doctrines mentioned in the earlier discussion of the territorial principle. ${ }^{135}$

The United Kingdom, the primary target of the 1960's-era pirates, has, however, been more conservative than the United States in relying on other-than-territorial principles of jurisdiction. ${ }^{136}$ Its conservatism is understandable given the susceptibility of nonterritorial theories, such as the protective principle, to abuse by virtually unlimited expansion. ${ }^{137}$ It is thus unlikely that a state following such conservative interpretations of jurisdiction would have adopted the protective principle as a basis for suppressing pirate radio broadcasting. On the other hand, most European states have been less reluctant than the British to utilize nonterritorial theories of jursidiction, ${ }^{138}$ and in light of their practices, the protective principle would have provided them with a firm base for enforcement action within the territory of the enforcing state.

\section{Nationality as a Basis for Jurisdiction}

Under current concepts of international law, nationality is also a basis for the exercise of prescriptive jurisdiction, and in some cases, enforcement jurisdiction as well. ${ }^{139}$ Where a person, corporation, vessel or aircraft has the nationality of a state, that state has jurisdiction to make rules governing the conduct of that person, corporation, vessel or aircraft. In addition, in the cases of ships and aircraft, that state may make rules governing the conduct of non-nationals while on board. ${ }^{140}$ Where the conduct takes place on the high seas, the jurisdiction of the state of nationality would normally be exclusive, but if conduct occurs within the territory of another state or in a place where that other state exercises some form of jurisdiction, concurrent jurisdiction might exist. ${ }^{141}$ Concurrent jurisdiction may also exist where the conduct of a national of one state takes place on board a ship or aircraft having the nationality of a second state. ${ }^{142}$

135. See supra text accompanying notes 103-30.

136. RESTATEMENT, supra note $103, \S 33$ reporter's note. See also supra note 109.

137. See, e.g., Judgment of Nov. 13, 1951, Hoge Raad der Nederlanden, [1952] Nederlandse Jurisprudentie [N.J.] 42; Public Prosecutor v. L, 18 INT'L L. REP. 206 (Netherlands 1951). Great Britain's conservatism with respect to extensions of jurisdiction seaward during the period the radio pirates were active is understandable when viewed in light of other law of the sea controversies Britain was engaged in during this period. The continuing dispute with Iceland over the extent of Iceland's fisheries jurisdiction was perhaps the foremost of these. Obviously a desire not to provide Iceland with a precedent of unilateral claim to ocean jurisdiction served as a deterrent to any claim by the British Government to exercise jurisdiction beyond the traditional three mile limit. In addition, all of the maritime states were engaged in a holding action to preserve a narrow territorial sea and to fight off continuing encroachments on the freedom of the seas through myriad claims to special zones and regimes of exclusive national jurisdiction.

138. See, e.g. , Judgment of Nov. 13, 1951, supra note 137; French Code of Criminal Protection (1925), art. 7, guoled in translation in $6 \mathrm{M}$. WHITEMAN, DIGEST OF INTERNATIONAL LAW 270 (1968).

139. Blackmer v. United States, 284 U.S. 421 (1932); RESTATEMENT, supra note 103, §§ 31, at 32. See J. Sweeney, C. Oliver \& N. Leech, Cases and Materials on the International Legal SYStem 125-26 (2d ed. 1981) for a brief survey of the practices of states as to the exercise of prescriptive and enforcement jurisdiction based on the nationality principle. See also L. HENkin, R. PUGH, O. SCHACHTER \& H. SMIT, INTERNATIONAL LAW 445-47 (1980), for a similar summary.

140. RESTATEMENT, supta note $103, \S \S 30-32$.

141. The S.S. Lotus, [1927] P.C.I.J., Ser. A, No. 10; High Seas Convention, supra note 50, arts. 6, 11.

142. Enforcement jurisdiction at sea, however, could be exercised only by the flag state. High Seas 
The nationality principle of jurisdiction thus presents considerable potential power to a state attempting to suppress pirate radio broadcasting. Such a state could, without violating international law, enact domestic legislation or regulations making it unlawful for one of its nationals (personal or corporate) to operate a pirate radio station, to aid or assist in the operation, to advertise on the station, to be employed by the station, or to do any of the myriad things required to keep a station in operation. Additionally, a state could prohibit any ship or aircraft having its nationality from permitting a broadcasting station to be operated on board by anyone of any nationality and could here, as above, prohibit ships or aircraft from aiding or abetting the operation of a station by acting in any sort of tender- or supply-ship capacity. ${ }^{143}$

Enforcement under the nationality theory would be less of a problem than under either of the theories previously discussed because enforcement jurisdiction follows prescriptive jurisdiction as to nationals on the high seas. ${ }^{144}$ As to fixed platforms, the ambiguous status of which has already been described, the coastal state would .be free to proceed against any activities conducted by its nationals on board. Shipboard stations, however, would present a problem if the ship were registered in any state other than the state attempting enforcement action. Although the state of nationality's laws would, in theory at least, reach the national on board, the foreign flag of the ship would shield the national and all activities and persons on board from investigation or enforcement by the nonflag state as long as the ship remained on the high seas. ${ }^{145}$ Since most ships housing pirate stations would choose to register in states other than the state off whose coast they are operating, ${ }^{146}$ the coastal state would usually be frustrated in its enforcement efforts against the ship itself. It could, nevertheless, as in the case of enforcement actions under objective-territorial or protective principles, fall back on enforcement against those persons and constituent activities of the broadcasting operation that might be found within its own territory. ${ }^{147}$

Of course, a broadcasting station might be operated as a totally foreign enterprise-foreign flag ship, foreign corporation, foreign personnel, foreign advertisers, support from foreign bases, etc.-in which case jurisdiction based on nationality would be of no use to the target state. But the prospects for a station's long-term survival under those circumstances would appear to be small, ${ }^{148}$ and the circumstances themselves unlikely.

Convention, supra note 50, arts. 6,11. Cf. Convention on Offenses and Certain Other Acts Committed on Board Aircraft, Sept. 14, 1963 , supra note 52, art. 11.

143. Enforcement action based on these principles, as well as on territorial jurisdiction, was the theory on which the European Agreement on Pirate Broadcasting, supra note 118, was based. Each party's use of conventional principles of territorial jurisdiction and jurisdiction over nationals in a cooperative way ultimately proved effective in closing down pirate broadcasting. See infra text accompanying notes 180-85. 795 .

144. High Seas Convention, supra note 50, art. 6; Cf. M. MCDOUGAL \& W. BuRKE, supra note 51, at

145. High Seas Convention, supra note 50, art. 6.

146. Radio Caroline was reported to be unregistered; "Caroline South" was reported to be registered in Panama. Smith speculates that both had second countries of registration to which they could resort in an emergency. Pirale Broadcasting, supra note 35 , at $811-12$.

147. See supra text accompanying notes 108-18, 143.

148. See supra text accompanying notes 113-15. But Radio Caroline continued to broadcast for some time following the enactment of the British Marine, \&c., Broadcasting (Offences) Act, 1967, apparently by 
A variation of the nationality principle was adopted by the Scandinavian states to enable them to take more effective action against radio pirates off their shores. On recommendation of the Nordic Council, the governments of Denmark, Finland, Iceland, Norway, and Sweden passed substantially identical legislation against pirate broadcasting. A feature common to each nation's legislation was a provision that the nationals of any of the five countries were to be treated as if they were nationals of the legislating state. ${ }^{149}$ This jurisdiction-by-consent greatly expanded the reach of their prescriptive acts and removed impediments to enforcement that might have been caused by the foreign nationality of the person, ship or corporation. ${ }^{150}$

\section{Contiguous Zone Jurisdiction}

A jurisdictional theory that at first glance might appear to have some applicability to the control of pirate radio stations is the contiguous zone concept. ${ }^{151}$ On closer examination, however, its principles, at least those codified in the $1958 \mathrm{Con}$ vention on the Territorial Sea and Contiguous Zone, ${ }^{152}$ do not provide a very fruitful source of authority.

The contiguous zone concept authorizes a state to extend its jurisdiction beyond the edge of its territorial sea. That jurisdiction is, however, limited in three respects: (1) the competencies authorized are limited to four, namely, customs, fiscal, immigration, and sanitary controls; ${ }^{153}$ (2) the enforcement actions of the coastal state are limited to preventing and punishing infringements committed (i.e., having their effect) within the territory or territorial sea of the state; ${ }^{154}$ and (3) the outer limit may not extend more than twelve miles from the baseline from which the territorial sea is measured. ${ }^{155}$ The second of these limitations presents no problem since the cffects of the pirate radio broadcasting are meant to and do have an effect within the territory of the coastal state. ${ }^{156}$ The other two limitations, however, doom the usefulness of this jurisdictional theory in suppressing pirate radio broadcasting. The twelve-mile outer boundary imposes a severe limitation on the enforcement power of the coastal state. The requirement for the broadcasting station to move out an additional nine miles ${ }^{157}$ would result in certain inconveniences (deeper water for anchoring, rougher seas for cruising) and

arranging for servicing and advertising outlets in a number of places outside Great Britain. See Pirate Broadcasting, supra note 35 , at $811-12$.

149. Hunnings, supra note 2 , at 419.

150. The common Nordic legislation proved effective in eventually closing down the stations targeting the Scandinavian states. However, Radio Syd proved extremely resilient, resuming transmission repeatedly after its director was fined for unauthorized possession of broadcasting equipment and even after he was sentenced to imprisonment. Id. at 420 .

151. See Territorial Sea Convention, supra note 61, art. 24.

152. Territorial Sea Convention, supra note 61.

153. Id. art. $24(1)(\mathrm{a})$.

154. Id art. $24(1)(\mathrm{a})$, (b).

155. Id. art. 24(2). The Draft Convention on the Law of the Sea, if adopted, would extend the outer limit to 24 miles from the baseline. U.N. Doc. A/CONF.62/L.78, Aug. 28, 1981, art. 33(2).

156. See supra text accompanying notes 100-02.

157. Or 12 miles beyond the outer limit of the territorial sea if the Draft Convention on the Law of 
would shorten the radio broadcaster's effective range by a corresponding distance. Nevertheless, the effects probably would not hamper the broadcaster to such a degree as to make the operation commercially infeasible. A pirate might be forced to use more seaworthy vessels and to increase the power of the transmitters, but the pirates have shown themselves able to cope with more serious problems than these. The real limitation on the use of the contiguous zone concept as a potential basis for controlling pirate radio broadcasting is that the contiguous zone, as shaped by the International Law Commission and adopted in article 24 of the 1958 Convention on the Territorial and Contiguous Zone, is a narrow, rigid, and what McDougal and Burke describe as "decidedly anachronistic" version of a concept which traditionally and by state practice has been flexible and dynamic. ${ }^{158}$ The competencies which a coastal state may exercise are limited to the protection of four named categories of interests (customs, fiscal, immigration, and sanitation). Although it has been suggested that a state might use the contiguous zone as a means of controlling pirate broadcasting by analogizing pirate broadcasting to the categories of interests named in article $24,{ }^{159}$ such a stretching of the article seems directly contrary to its wording and entirely inconsistent with the history of its development. As pointed out by McDougal and Burke, the article reflects principally the views of Sir Gerald Fitzmaurice, then an influential member of the ILC, who in turn reflected the consistent conservative attitude of Great Britain toward extending national authority beyond the territorial sea. ${ }^{160}$ Given this history and these limitations, it is not surprising then that none of the states targeted by pirate broadcasters used the contiguous zone as a legal basis for enforcement action against such broadcasters.

\section{E. Universal Jurisdiction}

As previously mentioned, the Convention on the High Seas provides that the authorities of any state may seize a pirate ship or aircraft on the high seas and that the courts of the seizing state may decide upon the penalties to be imposed on the pirates and the action to be taken against the ships, aircraft and property seized, subject to the rights of the third parties acting in good faith. ${ }^{161}$ This "universal" jurisdiction is justified on the basis that it is in the interests of all states to protect commerce and navigation on the high seas. If radio pirates were pirates in the legal sense, any state could exercise such enforcement jurisdiction. But radio pirates do not fit within the definition of piracy in the convention.

Nevertheless, one might argue that since all states have a common interest in preserving the public order of the airwaves over the oceans, the same rules should be applied to broadcasting pirates by analogy. Merely to state the proposition, however, is to refute it, for only the most extreme acts of violence and depredation on the high seas have been defined as piracy and recognized as subjecting the

the Sea, supra note 155 , is adopted, as article 3 of that convention adopts a 12 nautical mile breadth for the territorial sea.

158. M. MCDOUGal. \& W. Burke, supra note 51, at 605.

159. Pirale Broadcasting, supra note 35 , at 779-80.

160. M. MCDOUGAL \& W. BURKE, supra note 51, at 603-04. See also supra note 137.

161. High Seas Convention, supra note 50, art. 19. 
perpetrators to the universal jurisdiction of all states. Piracy acquired that status by virtue of customary international law. ${ }^{162}$

A number of other activities have received nearly world wide condemnation. ${ }^{163}$ These activities include slavery and engaging in the slave trade, traffic in women for prostitution (white slavery), traffic in narcotic drugs, interference with submarine cables, aircraft hijacking, genocide and crimes against the peace and security of mankind. Most states are parties to treaties obligating them to cooperate in suppressing such activities. ${ }^{164}$ With the possible exceptions of slavery, genocide and war crimes, ${ }^{165}$ enforcement jurisdiction over these activities is still dependent upon either some other basis of jurisdiction (such as nationality of the ship or person, or territorial jurisdiction over the place where the alleged crime occurred) or on treaty arrangements conferring jurisdiction on parties to the treaties. Although a great deal of study by both public bodies and individual scholars has been devoted to the creation of an international criminal law, it cannot be said that international law has developed to the point that it comprehends as crimes against international law acts other than piracy, and perhaps, as mentioned, genocide, war crimes and engaging in slave trade. Other "international" crimes are really violations of domestic law, to which the principle of territoriality of criminal jurisdiction is not recognized as a limiting factor, and which are defined as crimes by the laws of most states (offenses communis juris). ${ }^{166}$

162. The principle is of course now codified in the High Seas Convention, supra note 50, art. 19.

163. See RESTATEMENT, supra note $103, \S 34$ reporter's note 2.

164. Slavery: Convention to Suppress the Slave Trade and Slavery, Sept. 25, 1926, 46 Stat. 2183, T.S. No. 778, 60 L.N.T.S. 253; Protocol Amending the Slavery Convention, Dec. 7, 1953, 7 U.S.T. 479, T.I.A.S. No. 3532, 182 U.N.T.S. 51; High Seas Convention, supro note 50, art. 22. White slavery: Agreement for the Suppression of the White Slave Traffic, May 18, 1904, 35 Stat. 1909, T.S. No. 496, 1 L.N.T.S. 83. Traffic in narcotic drugs: Single Convention on Narcotic Drugs, Mar. 25, 1961, 18 U.S.T. 1407, T.I.A.S. No. 6298, 520 U.N.T.S. 204. Interference with submarine cables: Convention for the Protection of Submarine Cables, Mar. 14, 1884, 24 Stat. 989, T.S. No. 380; High Seas Convention, supra note 50, art. 27. Aircraft hijacking: Convention on Offences and Certain Other Acts Committed on Board Aircraft, supra note 52, Convention for the Suppression of Unlawful Seizure of Aircraft (Hijacking), supra note 52. Genocide: Convention on the Prevention and Punishment of the Crime of Genocide, Dec. 9, 1948, 78 U.N.T.S. 277 (the United States is not a party). Crimes against the peace and security of mankind (including war crimes): See G.A. Res. 95 (I), Dec. 11, 1946 (Affirmation of the Principles of International Law recognized by the Charter of the Nürnberg Tribunal). The General Assembly requested the International Law Commission to "formulate" the Nürnberg principles in a general codification of offenses against the peace and security of mankind or as an international code. 1 U.N. GAOR (Resolutions, 2d part) 188, U.N. Doc. A/64 (Add. 1) [1946-1947] U.N.Y.B. 254-55. The effort came to nothing, however. G.A. Res. 897 (IX), 9 U.N. GAOR Supp. (No. 21) at 50, U.N. Doc. A/2890 (1954). For a summary of the viewpoints of a number of scholars on this aborted effort, see $11 \mathrm{M}$. WHITEMAN, supra note 138, at 835-48; 1 id. at $201-07$. See also the 1949 Geneva Conventions relative to Wounded and Sick in Armed Forces in the Field, to Wounded, Sick and Shipwrecked Members of Armed Forces at Sea, to Prisoners of War, and to Protection of Civilian Persons in Time of War, Aug. 12, 1949, 6 U.S.T. 3217, 3250, 3336, 3516, T.I.A.S. Nos. 3362, 3363, 3364, 3365, 75 U.N.T.S. 31, 85, 135, 287. The four Geneva Conventions are supplemented by two additional protocols adopted at the United Nations Diplomatic Conference on Reaffirmation and Development of International Humanitarian Law Applicable in Armed Conflict, Geneva, June 8, 1977, U.N. Doc. A/32/144, Annexes I and II, reprinted in 16 INT'L Legal MATERIALS 1391 (1977). The additional protocols entered into force on December 7, 1978. As of the time of preparation of this article, the United States was not a party to the additional protocols.

165. Judgment of May 29, 1962, Sup. Ct. of Israel, [1962] 16 Piske Din 2033 (in Hebrew); Attorney General of Israel v. Eichmann, Judgment of Supreme Court of Israel, May 29, 1962, 36 INT'L L. REP. 277, 298-304 (1968). See RESTATEMENT, supra note 103, § 34 reporter's note 2.

166. See Parry, Some Considerations Upon the Content of a Draft Code of Offences Against the Peace and Security of 
As shall be seen below, even when the European states adopted a regional treaty on pirate broadcasting, they stopped short of bottoming enforcement on a universal jurisdiction concept. ${ }^{167}$ As shall also be seen, however, the Draft Convention on the Law of the Sea, emerging from the Third United Nations Conference on the Law of the Sea, moves in the direction of universalizing jurisdiction over broadcasting pirates. ${ }^{168}$

\section{F. The Dutch Approach}

The Netherlands evolved a unique legal theory to support action it took against pirate radio stations operating on fixed installations on its continental shelf but outside its territorial sea. Relying upon the work of an advisory commission on international law under the chairmanship of Professor J.P.A. Francois, ${ }^{169}$ the Netherlands Government enacted domestic legislation empowering its national authorities to act unilaterally against such installations. ${ }^{170}$ The claim to jurisdiction was based on the interlocking of three separate legal theories: the legal vacuum theory, the protection of legal interests theory and the notion of contiguity. As explained by van Panhuys and van Emde Boas, the Francois Commission and the Netherlands Government reasoned that " $[t]$ he absence of territorial sovereignty over the high seas has never meant, nor does it mean, that international law should tolerate a vacuum of legal authority or law."171 The permissive rules of international law therefore permit activities on the high seas to be regulated by national states (as, for example, ships by the authority of their flag state, or installations on the continental shelf for exploitation of the shelf's resources by their coastal state). The determination of which state is entitled to exercise jurisdiction, to fill the legal vacuum, in the case of installations on the continental shelf not for exploration or exploitation of the resources depends on two subsidiary principles-the protection of legal interests, and the notion of contiguity. ${ }^{172}$

According to the Netherlands Government, under the protection-of-legal-interests principle a state is entitled to exercise its jurisdiction outside its territory to protect certain legal interests, either those of the state itself (as, for example, the interests of the state in its regulatory control of the airwaves) or of the international community (as, for example, the international regulatory scheme for radio broadcasting). ${ }^{173}$ In its justification for its legislation, the Netherlands Government distinguished between the protection of "legal" interests and the protection of "vital" interests, such as self-defense. Actions to protect the latter could take place anywhere in the world, "albeit within the confines of international law," while the former were more narrowly confined geographically (as, for example, to

Mankind, 3 INT'L L.Q. 208, 211 (1950). For a sampling of the diversity of views on this subject see $11 \mathrm{M}$. WhITEMAN, supra note 138 , at $835-48$.

167. See infra text accompanying note 183 .

168. See infra text accompanying notes 186-99.

169. See van Panhuys \& van Emde Boas, supra note 14, at 315.

170. The North Sea Installations Act, Staatsblad 1964 No. 447, English transation printed as Annex to van Panhuys \& van Emde Boas, supra note 14, at 340-41.

171. Van Panhuys \& van Emde Boas, supra note 14, at 332.

172. Id. at 333-34.

173. Id. at 333 . 
the continental shelf). ${ }^{174}$ Even where so confined, however, the possibility of jurisdictional conflicts remained, since other states might purport to exercise jurisdiction under some other permissive theory of international law. Any such conflicts would then be solved by the second subsidiary principle of the legal vacuum theory, the notion of contiguity. ${ }^{175}$

The notion of contiguity suggests that for installations on the continental shelf, the nearest coastal state to the installation should have legal authority in preference to any other state. Such a jurisdiction is consistent with and analogous to existing jurisdictions in the contiguous zone, on the continental shelf and in offshore fishing zones. If coastal state jurisdiction. is necessary in those instances to 'protect the domestic and international legal order, then a similar necessity exists for installations on the continental shelf. ${ }^{176}$ The Netherlands Government insisted that such coastal state jurisdiction would be primary even though another state might be the owner of the installation. A fortiori, it would apply if the installation was privately owned. ${ }^{177}$

The Netherlands Government carried its notion of contiguity one step further, arguing that the coastal state had a responsibility as well as a right to exercise jurisdiction over fixed installations on the continental shelf. This responsibility required it to exercise its jurisdiction in such a way as to protect international interests that were not otherwise protected, here the international regulatory scheme for radio broadcasting. ${ }^{178}$

Following enactment of the Netherlands North Sea Installations Act, Netherlands authorities landed on the R.E.M. broadcasting installation and closed down its transmitter. No other state protested this action. ${ }^{179}$

\section{VIII}

\section{The European Agreement for the Prevention of Pirate Broadcasting}

As the foregoing discussion indicates, each coastal state troubled by the presence of offshore pirate broadcasters had adequate means within the arsenal of legal theories available to it under the permissive rules of international law to take effective enforcement actions against such broadcasters. The most effective measures probably would have been those that were directed against activities undertaken within the state's territory, as, for example, cutting off supplies and services or outlawing purchase of advertising by persons or entities within the territory of the coastal state. In the end, those were the measures actually adopted by the British Government, ${ }^{180}$ and they proved effective, ${ }^{181}$ but the British chose not to act until

174. Id.

175. Id. at 334

176. Id. at 334-35.

177. Id. at 335 .

178. Id. at 335 .

179. Id. at 336 .

180. British Marine, \&c., Broadcasting (Offences) Act, 1967, supra note 109, §§ 3-5.

181. See P. HARRIS, supra note 9 , at 165-95. 
the member states of the Council of Europe had adopted the European Agreement for the Prevention of Broadcasts Transmitted from Outside National Territories of January 22, 1965. ${ }^{182}$,That agreement, which entered into force October 19, 1967, represented the cooperative response of the European community to its common problem of pirate broadcasting. Rather than adopting some new or revolutionary theory of enforcement, however, the agreement signified merely a mutual undertaking actually to take the appropriate measures which traditional theories of jurisdiction already allowed against acts or actors within their territory or otherwise subject to their jurisdiction. ${ }^{183}$

Although the preamble to the agreement makes it clear that the parties are concerned about illegal broadcasting stations established on objects affixed to the seabeds as well as those on board ships, aircraft or other floating or airborne objects, article 1 limits the obligation of the parties to act only against those stations operated on floating or airborne objects. Article 4 , however, permits, but does not obligate, the parties to apply the provisions of the agreement "to broadcasting stations installed or maintained on objects affixed to or supported by the bed of the sea."

The key provisions of the agreement are contained in articles 2 and 3. Article 2 obligates each party to make punishable as offenses against its domestic law the establishment or operation of pirate stations installed or maintained on board ships, aircraft, or other floating or airborne objects, as well as knowing acts of collaboration. It then defines collaboration as including any of the following acts:

(i) the provision, maintenance or repairing of equipment;

(ii) the provision of supplies;

(iii) the provision of transportation for or transporting persons, equipment or supplies;

(iv) the ordering or production of any material, including advertisements, to be broadcast; and

(v) the provision of services concerning advertising for the benefit of the stations.

Article 3 obligates each party to apply the provisions of the agreement to both its nationals who have committed any of the acts referred to in article 2 on its territory, ships or aircraft or other floating or airborne objects, and to non-nationals who have committed any such acts on its territory or ships or aircraft or floating or airborne objects under its jurisdiction.

It can be seen, then, that the agreement created no new form of jurisdiction. What it did was obligate the parties to exercise the most universally accepted forms of national jurisdiction (territorial jurisdiction, jurisdiction over nationals, and jurisdiction over ships and aircraft having the nationality of the state) to make certain acts connected with pirate broadcasting unlawful and to enforce those laws within their territory against their nationals or on board ships or aircraft having their nationality.

182. European Agreement on Pirate Broadcasting, supra note 118.

183. Id. arts. 2, 3. 
While any individual state was already empowered to take any of those actions on its own, by providing uniformity and concert of action the agreement made acts by individual states more effective. If, for example, a pirate station targeting a continental state was being supported logistically from Great Britain, the British government would have been obligated to exercise its jurisdiction to terminate such support. Although one method of shutting down the station would have been to proceed against its advertisers, most of whom would probably have been in the target state, the complexity of corporate structures and product-distribution networks might have made it difficult to track down and prosecute the actual advertiser. ${ }^{184}$ Those who provided support services and persons directly connected with the operation of the station, on the other hand, would have been relatively easy to identify and prosecute.

More important than providing a jurisdictional framework for enforcement actions against pirate stations, however, was what the agreement represented. It was a collective statement of will to eradicate what had become a persistent source of disruption of the region's public order of the airwaves. By stiffening the backbones of the governments of the region, it ultimately led to the demise of the remaining pirate stations. ${ }^{185}$

IX

\section{The Draft Convention on the Law of the Sea of the Third United Nations Conference on the LaW of the Sea}

The preceding discussion has indicated that states targeted by pirate radio stations have at hand adequate jurisdictional bases for effective control measures against such stations, either through direct action against the stations or their platforms or through indirect actions against their suppliers, advertisers and other supporting structures. The Draft Convention on the Law of the Sea, ${ }^{186}$ if adopted and entered into force, will provide at least two additional jurisdictional bases on which direct action could be predicated.

The first of these is contained in the Draft Convention's provisions on the exclusive economic zone (EEZ) and would be applicable to stations located on artificial structures attached to the seabed. ${ }^{187}$ The second is an article in the high seas part of the Draft Convention specifically directed to the problem of unauthorized broadcasting stations located on the high seas or in the exclusive economic zone. ${ }^{188}$

Part $\mathrm{V}$ of the Draft Convention creates a new zone of the ocean, the exclusive economic zone. This zone is adjacent to but beyond the territorial sea to a limit of

184. See supra note 115. Radio Caroline adopted a number of artifices, including inserting "dummy" commercial messages among genuine ones, to make enforcement more difficult. See P. HARRIS, supra note 9 , at $177-94$.

185. See P. HARRIS, supra note 9 , at 165-95.

186. Draft Convention on the Law of the Sea, supra note 155.

187. Id. part $V$, arts. 55-75.

188. Id. art. 109. The provisions of article 109 will apply mutatis mutandis to the exclusive economic zone by virtue of article 58(2). See infra note 200. 
200 miles from the baseline from which the territorial sea is measured and is governed by a specific regime as set forth in that part. ${ }^{189}$ The purpose of the regime is to establish the sovereign rights of the coastal state in this zone for the exploration and economic exploitation of the natural resources of the seabed, subsoil, and water column, and for other activities such as the generation of energy. ${ }^{190}$ In order to effect this purpose, the coastal state is given the exclusive right to construct and to authorize and regulate the construction, operation and use of artificial islands, installations and structures for the purposes mentioned above "and other economic purposes."191 Although the drafters of the convention do not appear to have had pirate radio stations in mind when they included these provisions, ${ }^{192}$ their terms are drawn in sufficiently broad language to include such radio stations in their coverage. Unlike the provisions in the Continental Shelf Convention concerning structures on the shelf, ${ }^{193}$ which limit coastal state jurisdiction over artificial installations to those "necessary for [the shelf's] exploration and the exploitation of its natural resources," 194 the Draft Convention grants to the coastal state the exclusive right, without qualification, to "construct and to authorize and regulate the construction, operation and use" 195 of the artificial islands. ${ }^{196}$ As to the other artificial installations or structures, the authority of the coastal state is almost equally broad, limited only by the requirement that such installation or structures be constructed "for the purposes provided for in article 56 and other economic purposes." 197 Since the use of an artificial installation or structure for a radio broadcasting station would appear to be for an "economic purpose," the grant of authority to the coastal state would appear to include jurisdiction to regulate such use without trying to draw any precise distinctions as to whether the structure on which the station is located is an "artificial island" or some other type of "installation or structure."198

It would thus appear that the Draft Convention provides a heretofore unavailable jurisdictional basis for coastal state exercise of control over pirate radio stations located on platforms fixed to the seabed. Construing the provisions of part $\mathrm{V}$ in this manner does not appear to stretch them beyond their intended bounds nor to do violence to traditional notions of the proper limits for extraterritorial exercise of enforcement jurisdiction by coastal states. The necessity for employment of this

189. Draft Convention on the Law of the Sea, supra note 155 , part V, arts. $55,57$.

190. Id. art. 56(1)(a).

191. Id. art. $60(1)(\mathrm{a})$, (b).

192. The inclusion of article 109, directed specifically to the pirate radio problem, would lend support to this conclusion. See infra text accompanying notes 199-212.

193. Continental Shelf Convention, supra note 64 , art. $5 \S 2$.

194. Id. See supra text accompanying notes $62-67,85$.

195. Draft Convention on the Law of the Sea, supra note 155, art. $60(1)$.

196. Id. art. $60(1)(\mathrm{a})$.

197. Id. art. 60(1)(b). See supra text accompanying notes 190-91.

198. The Draft Convention on the Law of the Sea does not appear to contain any statement as to what constitutes an "artificial island" as opposed to an "installation" or "structure." Except for the separation of the terms in subsections (a) and (b) of article 60(1), the terms appear in tandem wherever used in parts V and VI of the Draft Convention. See Draft Convention on the Law of the Sea, supra note 155, arts. $56,60,79,80$. 
theory does not seem pressing, however, in the light of the more explicit provisions of article 109.

Article 109 of the Draft Convention reads:

1. All States shall co-operate in the suppression of unauthorized broadcasting from the high seas.

2. For the purposes of this Convention, "unauthorized broadcasting" means the transmission of sound radio or television broadcasts from a ship or installation on the high seas intended for reception by the general public contrary to international regulations, but excluding the transmission of distress calls.

3. Any person engaged in unauthorized broadcasting may be prosecuted before the court of:

(a) the flag State of the ship;

(b) the State of registry of the installation;

(c) the State of which the person is a national;

(d) any State where the transmission can be received; or

(e) any State where authorized radio communication is suffering interference.

4. On the high seas, a State having jurisdiction in accordance with paragraph 3 may, in conformity with article 110, arrest any person or ship engaged in unauthorized broadcasting and seize the broadcasting apparatus. ${ }^{199}$

An examination of the article's provisions discloses that it accomplishes several purposes. First of all, paragraph 1 places an obligation on all states (parties) to cooperate in suppression of unauthorized broadcasting from the high seas. ${ }^{200}$ Unauthorized broadcasting is defined broadly and in terms consistent with the international regulatory scheme discussed earlier (paragraph 2). Unauthorized broadcasting includes both radio and television broadcasting, and appropriately excepts distress calls.

Second, paragraph 3 establishes (or confirms, as the case may be) that prosecutorial jurisdiction may be exercised by states under several different circumstances. Exercise of such jurisdiction by the flag state of the vessel or the state of nationality of the persons involved is, as has been seen, consistent with traditional concepts of extraterritorial jurisdiction. Although the Draft Convention does not provide specifically for national registration of fixed installations and structures on the seabed of the continental shelf or in the exclusive economic zone, the plenary authority granted over such structures to the coastal state presumably includes the right to require registration within some state (and perhaps within the coastal state) as a condition for construction on the shelf or within the EEZ. ${ }^{201}$ Exercise of jurisdiction by the state of registration parallels flag-state jurisdiction over ships. The exercise of jurisdiction by a state where the transmissions can be heard or where authorized transmission is suffering interference can probably be fitted within the objective territorial or protective theories of jurisdiction.

In order to exercise its prosecutorial jurisdiction effectively, however, a state

199. Id. art. 109.

200. Although article 109 refers only to broadcasting from the high seas, its provisions are made applicable to the exclusive economic zone by article $58(2)$ which provides, "Articles 88 to 115 and other pertinent rules of international law apply to the exclusive economic zone in so far as they are not incompatible with this [exclusive economic zone] Part." Id. art. 58(2). Thus, there is no hiatus between the outer edge of the territorial sea and the beginning of the high seas at the outer edge of the exclusive economic zone.

201. See id. arts. 60,80 . 
must somehow obtain physical control over the person or ship involved. Paragraph 4 provides authority for states to accomplish this. In a radical departure from traditional notions of the freedom of the seas, paragraph 4 provides that states having jurisdiction to prosecute under paragraph 3 may arrest any person or ship engaged in unauthorized broadcasting and seize the broadcasting apparatus. Such arrest and seizure is accomplished through the exercise of the right of visit by warships or military aircraft (or other clearly marked ships or aircraft on government service) pursuant to article 110 .

This grant of authority to nonflag states represents a major departure from the freedom of the seas. The exclusive jurisdiction of flag states over their ships while on the high seas has been for centuries a jealously guarded principle to which only a very few exceptions have been recognized. ${ }^{202}$ Only where ships have been engaged in such flagrant abuses as piracy or sailing without evidence of nationality have states been willing to admit the right of warships of other states to stop and board their ships on the high seas. ${ }^{203}$ Even engaging in the slave trade was not recognized as a basis for such action, in the absence of a specific treaty, until the 1958 Convention on the High Seas. ${ }^{204}$ In view of this history, it would be expected that article 109 would have been highly controversial at the conference, but this does not appear to have been the case.

Article 109 was derived from a proposal submitted to the conference by nine states of the European Economic Community at the first negotiating session of the conference in Caracas in 1974. ${ }^{205}$ The only apparent references to the proposal in the official debates of the conference are a brief reference to the subject by the United Kingdom during the debate on the high seas, ${ }^{206}$ and an equally brief explanation of the proposal by the United Kingdom representative on behalf of its sponsors, in which he merely stated that he "hoped that its provisions would be included in any further working document on the subject."207 The proposal evoked no opposition and was included in the series of negotiating texts and the Draft Convention without substantive change or further discussion. ${ }^{208}$

202. See Report of the International Law Commission to the General Assembly, 11 U.N. GAOR, Supp. (No. 9) at 1, art. 46 commentary 1, U.N. Doc. A/3159 (1956), reprinled in [1956] 2 Y.B. INT'L L. CoMM'N 253, 284, U.N. Doc. A/CN.4/SER.A/1956/ADD.1 [hereinafter cited as ILC Report]; M. MCDOUGAL \& W. BURKE, supra note 51, at 870-72, 1057-66.

203. M. MCDOUGaL \& W. BURKE, supra note 51, at 870-72, 1057-66.

204. High Seas Convention, supra note 50, art. 22. See ILC Report, supra note 202, art. 46 commentary 1(ii), [1956] 2 Y.B. INT'L L.COMM'N at 284.

205. U.N. Doc. A/CONF.62/C.2/L.54, art. 21, 3 Third United Nations Conference on the Law of the Sea Official Records 230 (1974) [hereinafter cited as UNCLOS III OR].

206. Statement of Mr. Anderson (United Kingdom), Aug. 12, 1974, 2 id. at 237.

207. Statement of Mr. Dudgeon (United Kingdom), Aug. 14, 1974, 2 id. at 289-90.

208. Informal Single Negotiating Text, U.N. Doc. A/CONF.62/WP.8/ Part II, art. 95, 4 UNCLOS III OR, supra note 205, at 166; Revised Single Negotiating Text, U.N. Doc, A/CONF.62/ WP.8/ Rev.I/Part II, art. 97; 5 UNCLOS III OR, supra note 205, at 168; Informal Composite Negotiating Text, U.N. Doc. A/CONF.62/WP.10, July 15, 1977, art. 109; Informal Composite Negotiating Text/Revision 1, U.N. Doc. A/CONF.62/ WP.10/Rev.1, Apr. 28, 1979, art. 109; Informal Composite Negotiating Text/Revision 2, U.N. Doc. A/CONF.62/WP.10/Rev.2, Apr. 11, 1980, art. 109; Draft Convention on the Law of the Sea (Informal Text), U.N. Doc. A/CONF.62/WP.10/Rev.3, art. 109. Subsequent to the promulgation of the Draft Convention (Informal Text), the Drafting Committee recommended certain nonsubstantive changes in wording and rearrangement of the paragraphs of the article. These were adopted at 
The reasons that article 109 sailed through the conference so easily are not readily evident. The officially recorded conference proceedings are silent on the issue except for the brief references previously noted. ${ }^{209}$ The problem addressed by the article was certainly not an urgent one. The heyday of pirate broadcasters in Northern Europe had long since passed, and the Northern European states that sponsored the proposal seemed already to have solved by more conservative means any problems that had previously existed there. ${ }^{210}$ States that might have been expected to oppose such a proposal may have been preoccupied with what they perceived as more important issues such as passage through straits, fishing, deep sea mining and the like. Other states not as troubled by encroachments on the freedoms of the high seas may have seen this development as only one more manifestation of a conference trend to extend the reach of national jurisdictions of one sort or another farther and farther to sea. ${ }^{211}$ Still others, troubled by propaganda broadcasts aimed at them from the territories of other states, may have seen this as an opportunity to establish the unlawfulness of such practices. ${ }^{212}$ Whatever the reasons for its inclusion, however, article 109 establishes a troubling precedent. If the nations of the world, particularly those that regard themselves as guardians of the freedom of the seas, are willing to accept such a significant exception to the principle of the exclusive jurisdiction of the flag state over ships on the high seas on the basis of such weak justification to solve a largely nonexistent problem, other steadfastly held principles may be in similar jeopardy. One can hope that article 109 does not represent a general trend away from exclusive flag-state jurisdiction, but other developments in the conference would suggest that this is not the case. ${ }^{213}$

\section{$\mathrm{X}$ \\ Conclusion}

Well-established international law theories of jurisdiction are flexible enough to provide an effective array of enforcement mechanisms to any state targeted by a commercial pirate radio or television station operating from a platform on the high seas floating or affixed to the seabed. No new or exotic theories need to be invented to allow a state to close down a troublesome pirate. The European Agreement of 1965 is helpful in that the parties pledge cooperation by acting in their own territories and against their own nationals to shut off support for radio stations targeted against other states but supported from within their own boundaries. This assists a target state in cases in which the only support for the station

the resumed tenth session of the conference in August 1981 and incorporated into the Draft Convention. See U.N. Chronicle, Sept. 1981, at 21.

209. See U.K. statement, supra note 201.

210. See supra text accompanying notes 183-85.

211. Under the Draft Convention on the Law of the Sea, supre note 155, the territorial sea is extended to 12 miles (art. 3), the contiguous zone to 24 (art. 33), the continental shelf to 200 or 350 miles or beyond (art. 76), and large areas formerly high seas would become archipelagic waters of certain island states (arts. 46-54). Every coastal state would be entitled to an exclusive economic zone extending as far as 200 miles (art. 57).

212. See Comment, Controlling "Pirale" Broadcasting, 15 San Diego L. REV. 547, 568-69 (1978).

213. See supra text accompanying note 211. 
generated in that state is advertising revenue, and where the sources of that revenue may be difficult to identify because of the complexities of corporate structure.

On the other hand, the adoption of article 109 of the Draft Convention on the Law of the Sea is an exercise in overkill. To grant to any state in which a broadcast can be received the authority to board a ship or installation and to arrest and prosecute the persons or ships involved is a drastic departure from the traditional freedoms of the high seas and the principle of the exclusive jurisdiction of flag states over ships flying their flags. If there were no other means to deal with the problem, and if the interest sought to be protected were more vital, perhaps such a radical departure from the traditional regime would be warranted. But in light of the effectiveness of the actions which states have been able to take and the current dormancy of the problem, the draft treaty provision hardly seems warranted. It is surprising that its inclusion did not provoke opposition at the conference. It represents another example of the strong tendencies evident at the Third United Nations Conference on the Law of the Sea to discard traditional freedoms of the seas in favor of restrictive and territorial regimes. 
